\title{
Implementing the G20/OECD Principles of Corporate Governance: What is the Progress in BRICS and Indonesia? ${ }^{1}$
}

\section{T. Lanshina}

Tatiana Lanshina - Research associate, Centre for the Economic Modelling of Energy and Environment, Russian Presidential Academy of National Economy and Public Administration; Research associate, Centre for Industrial Studies, Institute for U.S. and Canadian Studies; 82 Prospect Vernadskogo, Building 1, 119571 Moscow, Russian Federation; E-mail: lanshina.ta@gmail.com

The article analyses the implementation of the G20/OECD Principles of Corporate Governance by Russia in comparison to other BRICS countries and Indonesia. Originally, this document was adopted by OECD in 1999. The last (third) version of the document was developed in 2014-2015, with an active involvement of G20 countries, and was adopted at the G20 Summit in Antalya (Turkey) in November 2015. Dramatic changes are absent in the new document, however, it contains several new recommendations, which became necessary after the global economic crisis of 2008-2009.

The article is focused on the actions of six countries that were chosen for the analysis, as well as on the real changes in these countries. The author takes into account OECD recommendations on the assessment of implementation of G20/OECD principles. According to these recommendations, researchers should not pay too much attention to the quantitative analysis, since many important issues are unobservable for them. Considering this, the author accentuates qualitative research methods and comparative analysis. The results of the study show that Brazil, Indonesia and Russia were most active in implementation, while South Africa and China lacked any actions, and India achieved only partial implementation.

Despite the large number of facts documenting formal implementation of corporate governance principles in Russia during the last years, Russia definitely lacks real improvements. This is true for information disclosure (including data on the management remuneration), gender diversity on corporate boards, the share of independent directors, etc. Moreover, Russian companies are characterized by high concentration of capital, and the role of boards is often reduced to formalities. According to the results of the research, similar limitations are found in the systems of corporate governance of other countries covered by this study. Taking into account the limited accessibility of information on real changes and real implementation in other BRICS countries and Indonesia, the author assesses the Russia's efforts as "substantial implementation", though due to the presence of gaps between actions and changes, Russia's efforts should be assessed as "partial implementation."

Key words: corporate governance; G20; OECD

For citation: Lanshina T. (2017) Implementing the G20/OECD Principles of Corporate Governance: What is the Progress in BRICS and Indonesia? International Organisations Research Journal, vol. 12, no 3, pp. 137-159 (in Russian and English). DOI: 10.17323/1996-7845-2017-03-137

${ }^{1}$ The editorial board received the article in January 2017.

The research was carried out within the framework of the RANEPA research project "Comparative study of BRICS member countries and Indonesia approaches to OECD instruments implementation” (2017 г.) 


\section{Introduction}

OECD Principles of corporate governance were first adopted in 1999. Very quickly they gained a reputation of an authoritative international benchmark for good corporate governance, which began to widely disseminate among OECD countries and beyond this organization. Later the document was twice revised; the last revision was conducted in 2013-2014, as a response to the global financial and economic crisis of 2008-2009. It should be noted that insufficient quality of corporate governance played quite a considerable role in the crisis events.

The last, third, version of the Principles of corporate government was developed by OECD with an active involvement of G20 countries, including developing countries that have no OECD membership. This is why this version was called G20/OECD Principles of corporate governance [G20/OECD, 2015]. The revised document was adopted in November 2015 at the G20 Antalya summit [University of Toronto, 2015]. Presently, almost two years after its adoption, the main issue is the implementation of the revised Principles.

The goal of this article is to find key facts of the implementation of the new document in BRICS countries and Indonesia, as well as to conduct a comparative analysis of these facts in Russia and other countries selected for the study. The author used qualitative analysis methods: comparative study and content analysis of the international documents and reports. Following OECD recommendations and taking into account the drawbacks and limitations of quantitative evaluations due to substantial differences in the national systems of corporate governance and in focuses of countries that implement the new document, the author abandoned the idea of using quantitative evaluation techniques.

\section{Key Changes of the 2015 Version of Principles}

Before starting the analysis of the implementation of the new principles of corporate governance itself, it is necessary to shortly review the major changes of the 2015 edition. It should be noted that the wording of the principles in the new version has little changed. The 2015 document has only one new paragraph ("Institutional investors, stock markets, and other intermediaries"), but its text was partially taken from the "The Equitable Treatment of Shareholders" paragraph of the 2004 document [Larionova, Lanshina, 2016]. The text of the Principles itself has undergone more substantial changes which are shorly reviewed below.

The first principle of the 2015 edition ("Ensuring the basis for an effective corporate governance framework") gained two new subparagraphs. In the new text it is noted that effective corporate governance should be supported by the stock market regulation. Quality of stock market rules is an important element of the corporate governance system. Regulatory and supervisory authorities should assess the role of stock exchanges in corporate governance. Also, the new principles call for the intensification of cross- 
border cooperation, including through bilateral and multilateral arrangements for the exchange of information. Evidently, these new provisions are a reaction on the global financial and economic crisis of 2008-2009.

The new version of the document notes that legislative and regulatory elements of the corporate governance system should be complemented by soft norms based on the principle of "comply or explain," for example, by corporate governance codes. This will provide flexibility and allow to take into account the characteristics of individual companies. Government agencies should be endowed with powers in law enforcement and sanctions. Supervisory, regulatory and law enforcement agencies should be independent and accountable. According to the document, in many countries, the problem of the stock market supervisory body independence was solved by creating councils or commissions whose members were appointed for a certain period of time. Appointments that are not binded to the political calendar, as well as non-simultaneous appointments contribute to the independence of such a body.

The second principle ("The rights and equitable treatment of shareholders and key ownership functions") of the new edition was complemented by a subparagraph prohibiting impediments to cross border voting. Problems with cross border voting usually arise because foreign investors often own their shares through complex cross border intermediary chains. To avoid impediments to cross border voting, it should be clear who is eligible to vote in such situations. One more novelty - the requirement to approve related-party transactions and to address the conflict of interest in such transactions in a proper manner. Top managers and board members should provide information on material interest in transactions that have relation to the company.

Also, according to the new edition, all shareholders should be equally treated; impediments to voting (i.e., sending voting material just ahead of the shareholders' general meeting, charging fees for voting and other unfair practices) should be avoided. The 2015 version stresses that shareholders should be informed about the compensation policy, as well as about the total volumes of compensation and its forms. Companies and countries should facilitate the use of information technologies to promote voting by shareholders.

Third and fourth principles ("Institutional investors, stock markets, and other intermediaries" and "The role of stakeholders in corporate governance") contain very few changes. Commentaries to the third principle list the key challenges facing corporate governance in the last decade and note that the corporate governance system should give the right signals to the investment chain as well as provide conditions, under which the work of stock markets will have a positive influence on the effective corporate governance. To the fourth principle it was added that international conventions and national rules admit the right of employees on information, consultation and negotiation. In the new Principles, company's clients are included in the list of stakeholders, in line with investors, employees, creditors and suppliers.

The fifth principle of the 2015 edition ("Disclosure and transparency") notes the desirability of company's non-financial information disclosure (e.g., donations, made 
for political reasons). In some countries the disclosure of that kind of information is obligatory for large companies. The text of the principle also notes the desirability of information disclosure on compensation and employee representation mechanisms. Some countries place requirements to corporate websites with regard to providing upto-date and significant information.

The 2015 version of the document misses the last subparagraph of the fifth principle, that was present in the 2004 edition. According to this subparagraph, the system of corporate governance should admit and facilitate cooperation of companies with analysts, rating agencies and other organizations. According to the 2004 edition, such cooperation is necessary for investors to make decisions that are free of conflict of interests. Obviously, this change is the consequence of the 2008-2009 global crisis.

The sixth principle of the 2015 edition ("The responsibilities of the board") accentuates the growing importance of board's control for risk management. This kind of control should comprise oversight of the accountability and responsibility for managing risks, with attention to types and degrees of risk that company is willing to take. Moreover, according to the new version of principles, boards should consider the establishment of additional specialized committees to improve the performance of the whole board. In particular, this relates to audit, compensation policy and risk management. Also the boards should conduct regular evaluations of their performance.

Summing it up, the revised version contains a number of important updates, though the changes are hardly dramatical. After the financial and economic crisis of 2008-2009, one could or even should have expected a greater revision. Apart from that, the new document still considers economic results in a very narrow context, without due attention to ecological aspects, life quality issues and sustainable development goals [Larionova, Lanshina, 2016].

\section{Methodology for Assessing the Implementation of the G20/OECD Principles of Corporate Governance}

Key priorities and opportunities in the sphere of G20/OECD Principles of corporate governance implementation were quite clearly formulated by the Business and industry advisory committee (BIAC) in April 2016 (in its commentaries on future OECD work). According to the commentaries of BIAC, the practical implementation should consider country specifics, including cultural background and opportunities; equally important is to take into account the results of OECD corporate governance reports [BIAC, 2016].

A draft methodology for assessing the implementation of the principles was published by OECD in an annex to its Progress report on the implementation of the G20/ OECD Principles of corporate governance [G20/OECD, 2016]. The final methodology was published in 2017 [OECD, 2017a].

Both draft and final versions of the methodology contain clarifications on the key aspects of the new edition of the Principles and suggest using the following conclusions on the implementation: fully implemented, broadly implemented, partially im- 
plemented, not implemented and not applicable. As noted in the final version of the methodology, though some quantitative indicators may be taken into account, the reviewer should not reduce his or her assessment to scoring or to the analysis of a set of quantitative indicators [OECD, 2017a].

Moreover, all versions of the Principles admit the absence of a unified model of effective corporate governance; therefore, the Principles were formulated rather generally, so that countries could interpret and implement them with regard to their legislative, historical, cultural and other specifics. This additionally compicates quantitative research and makes it of little use.

According to the OECD recommendations on the implementation of the Principles, one should assess the legal framework and implementation measures, corporate practices, as well as the functioning of markets. The analyst should take into account, that the methodology is focused on jurisdictions, not on certain companies. Since practice of corporate governance in different companies of the same jurisdiction often vary, it is questionable, how widespread a practice should be or how strong a violation of the recommendation should be, to conclude that a jurisdiction is or is not implementing the principle. Taking into account all above, it is quite difficult to develop a clear evaluation guide. As is stated in the document, the best approach to evaluation may be orientation on the qualitative analysis and common sense. Also, according to the Methodology for assessing the implementation of the G20/OECD Principles of corporate governance, the analysis should be deep enough to make conclusions whether the principle has been implemented not only theoretically but also practically [OECD, 2017a].

In this study the author takes into account the recommendations of the official guide on assessing the implementation of the revised G20/OECD principles of corporate governance [OECD, 2017a], refusing of quantitative assessments and relying on common sense. The author conducts a comparative study of the major implementation facts in Russia and other BRICS countries as well as Indonesia.

\section{General Features of the Corporate Governance in BRICS Countries and Indonesia}

We will start by detecting the general corporate governance features in the selected for this study countries. As noted in the report of the International Organization of Securities Commissions (IOSCO), which was published in October 2016, regulatory framework in the developing countries is generally compatible with the recommendations of the G20/OECD Principles of corporate governance. The IOSCO report analyses corporate practices of all selected for this study countries except for Indonesia by three key aspects of corporate governance: formation of the board, compensartion and motivation mechanisms, risk management and internal control [IOSCO, 2016].

Nevertheless, in general, systems of corporate governance and capital markets of the selected for this study countries are insufficiently mature and need further improvements. Their specifics include highly concentrated ownership structure, low shares of 
independent directors, low transparency, high level of corruption, large number of corporate scandals. Rules and laws that regulate the rights of creditors and shareholders in the selected for this study countries are often used in practice in different manners [IMF, 2016].

The quality of corporate governance in China, India and Indonesia is considered to be rather low even among the Asian countries. These countries are at the end of the corporate governance rating which is compiled once in two years by the Asian Corporate Governance Association (ACGA). According to the last rating, compiled in September 2016, among 11 Asian countries three first places were taken by Australia, Singapore and Hong Kong. India came $7^{\text {th }}$, China $-9^{\text {th }}$, Indonesia $-11^{\text {th }}$. India managed to improve its results compared to 2014 by one point, China's score declined by two points, though the authors of the rating admitted improvements in the Chinese practice of corporate governance. Indonesia's score declined by three points [CG Watch, 2016].

\section{Formal Implementation of the Revised Principles: Russia and other BRICS Countries as well as Indonesia}

Back in 1990s, the corporate governance in Russia was flawed and underdeveloped. Companies often neglected interests and rights of their minority shareholders, their activities had low transparency, and their practices of corporate governance were of poor quality. All these factors formed their negative image abroad and discouraged investment. Then, largely due to the expansion of Russian companies in foreign markets, the situation began to improve, among other things because of the pressure from foreign partners. A similar situation was observed in many other BRICS countries and in Indonesia, where international cooperation has also played the role of main driver of positive changes in corporate governance.

The main laws regulating corporate governance in Russia are the federal law No. 208-FZ of 26 December 1995 "On public companies" (with amendments; the last amendment was introduced in 2016), the federal law No. 14-FZ of 8 February 1998 "On limited liability companies" (with amendments; the last amendment was introduced in 2015), and the federal law No. 39-FZ of 22 April 1996 "On the securities market" (with amendments; the last amendment was introduced in 2015).

The basis of responsible corporate governance in Russia is formed by a number of documents adopted in the 2000s, long before the G20 countries began to actively participate in updating the OECD Principles of corporate governance. In 2002, the congress of the Russian Union of Industrialists and Entrepreneurs (RSPP) adopted the Charter of corporate and business ethics. In 2004, the congress of RSPP adopted the Social charter of Russian business; in 2008, this document was amended. In 2012, Russia introduced the Guidance on social responsibility (international standard ISO 26000) for the first time.

Russia is characterized by high ownership concentration in public companies. In 2014, in about 43 percent of 96 Russian largest public companies, one owner or one 
group of owners had more than 75 percent of shares. A similar situation is observed in most other countries, especially in the developing world. Only four countries in the world are characterized by a largely disseminated structure of corporate ownership Australia, Ireland, Great Britain and the USA. U.S. public companies are seldom controlled by a major shareholder. The share of a major shareholder in 90 percent of British companies with LSE listing is 25 percent or less. As to other selected for this study countries, the situation does not differentiate much from the situation on Russia. In Brasil, most public companies are controlled by a single shareholder, a foreign company or a corporate group. According to estimates, more than 70 percent of Brazil companies have family or share ownership. In Indonesia, 70 percent of shares of listed firms are held by controlling shareholders, and 54 percent of the total market capitalization is held by family business groups. Most South African listed companies have a controlling shareholder or shareholders [OECD, 2017b].

Russia has recently done much to improve the quality of its corporate governance. In September 2013, the Bank of Rusia acquired the functions of the Russian Federal Service for the Financial Markets (FFMS) and became a mega-regulator of the Russian financial market. The list of its functions now includes corporate governance regulation, among other things. In this regard, the Bank of Russia began to conduct explanatory and methodological work with public companies aimed at improving the quality of corporate governance. The Bank of Russia has also shown its intention to actively work to improve corporate governance in Russia and avoid formalism in tackling this issue. Along with other tasks, according to the Russia's Central Bank representatives, the coming years will see the growing necessity to increase the shareholders'activity in corporate decisions and in increasing transparency of top management compensation policies [OECD, 2016a].

Russia and other selected for this research countries adopted their corporate governance codes 15-20 years ago. The first ${ }^{2}$ was South Africa - it adopted its first code in 1994. The Indian code of corporate governance was published in 1998, the Indonesian one - in 2000, the Chinese one - in 2001, the Russian one - in 2002, the Brazilian one - in 2004 [European Corporate Governance Institute, 2016].

In 2014, the Bank of Russia approved the new Code of corporate governance (companies comply with its provisions on a voluntary basis; this code is an instrument of soft governance), containing dramatic improvements compared to its earlier 2002 version. For instance, it lists not only expected company performance, but also recommendations on strengthening information disclosure policies and on protection of shareholders' rights, on board composition (the criteria for the board member independence clarified, the recommended share of independent directors increased from one quarter to one third), on board performance assessment, on top management and board members' compensation policies, on dividend policies, etc. The code was ap-

${ }^{2}$ Earlier than other selected for the study countries. 
proved by the board of the Bank of Russia and recommended to public companies ${ }^{3}$. It is based on the OECD Corporate governance principles.

Now the most important task is the implementation of the updated code, and Russia makes much effort to accomplish this task [IMF, 2016]. Thus, in its letter of 17 February 2016, the Bank of Russia published a list of recommendations on compliance with the Code's principles and guidelines. These recommendations concern the disclosure of information on such aspects of corporate governance as the composition of the board, the effectiveness of the decision-making process, the role of major shareholders, transactions with related parties, risk management, internal control, etc. [Tsentral'nyy Bank Rossiyskoy Federatsii, 2016]. In 2016, the Ministry of Finance prepared amendments to the law "On Banks and on Banking Activities," according to which, financial organizations must carry out transactions with related parties on market terms [Financial Stability Board, 2017].

In recent years, several other selected for this study countries have revised their corporate governance codes. For example, in 2014-2015, key associations of Brazil public companies (ABRASCA, AMEC и IBGC) joined their efforts to develop the fifth revised version of the voluntary corporate governance code. This initiative was supported by the Securities and Exchange Commission of Brazil and by the Brazilian Development Bank, which were involved in the development of the new version of the code as observers. The fifth version of the code was published in 2016 (the first one - in 1999), after the adoption of the G20/OECD Principles of corporate governance at the G20 Antalya Summit in 2015 [IFC, 2016]. Later the Securities and Exchange Commission of Brazil may oblige all public companies to comply with the guidelines of the code [ICLG, 2016].

The key principles of the fifth corporate governance code of Brazilian companies are transparency, fairness, accountability and corporate responsibility [IBGC, 2016]. In general, the code complies with the updated G20/OECD Principles of corporate governance, even on some aspects that have been insufficiently addressed in the G20/ OECD document itself, for example, on the company's responsibility for its impact on the social sphere and ecology, and also on the disclosure of information on such impact.

In 2014, Securities and Exchange Board of India (SEBI) approved a new code of corporate governance. Its goal is to increase the transparency of Indian public companies. The new document requires the introduction of a whistleblower policy, the disclosure of top management remuneration policy, the imposition of restrictions on the maximum number of boards that one director would be allowed to be a member of, as well as the presence of at least one woman on each board [Reuters, 2014]. Also, the presence of at least one woman on the board is required by the Companies Law of 2013.

Also in 2016, South Africa published a new King report on corporate governance, which in fact is a code of corporate governance. Preparation of the last - fourth -

${ }^{3}$ Since September 2014, the Civil Code of the Russian Federation classifies public and non-public jointstock companies; before that, it classified open and closed joint-stock companies (JSC and CJSC). 
King's report was necessary because of a significant change in corporate governance and its aspects at the international and national levels after 2009, when the third report was published. Interestingly, in King's latest report, the "comply or explain" principle is replaced by the "comply and explain" principle. In addition, the 75 principles of the third report are reduced and consolidated into 16 principles, which makes the structure of the new document more clear and simple. Special attention is paid to the compensation policies. The fourth version of the report recommends that both the remuneration policy and the report on its implementation should be put up for an optional consultative vote. The third report recommended to put up for a vote only remuneration policies. Also, the latest version of the report lists requirements to remuneration policy: it must attract, motivate, reward and retain human resources, contribute to the achievement of strategic goals within the acceptable risk limits of the organization, stimulate the achievement of positive results, promote ethical culture and responsible corporate behavior [Institute of Directors Southern Africa, 2016].

The most important tasks of the new King's report are the transition from formal implementation ("for a tick") to meaningful practical application of recommendations, as well as the use of the code not only among public companies but among all organizations. To fulfill these goals, the document delineates the principles and recommended practices. The focus of the new King report is business ethics and effective management: a company should not only bring operational results, it should also be successful in the overall economic, social and environmental contexts. The top management remuneration system should take into account not only the creation of shareholder value, but also the company's impact on the social sphere and environment [Institute of Directors Southern Africa, 2016].

In Russia, the implementation of the new G20/OECD document was discussed at the meetings of the OECD - Russia Corporate Governance Roundtable in October 2015 [OECD, 2016a] and in November 2016 [Natsional'naya assotsiatsiya korporativnykh direktorov, 2016]. Moreover, in 2015, the Moscow exchange and OECD created a Companies circle in the framework of the OECD-Russia Corporate Governance Roundtable, thus extending the format of this roundtable. Twelve largest Russian public companies became members of this circle. The main objective of the circle is to provide expert and organizational assistance to members of the club in order to improve their corporate governance [OECD, 2016a].

Apart from OECD - Russia Corporate Governance Roundtable, especially great work on the analysis of the specifics of the introduction of corporate governance principles and best practices in this area was carried out only by the OECD - Asian Roundtable on Corporate Governance (among its members are India, Indonesia and China). At the meeting of the OECD-Asian Roundtable on Corporate Governance on 29-30 October 2015 in Bangkok (Thailand), the participants discussed opportunities for practical use of the new Principles in Asian countries, its relevancy in the region and key implementation challenges. Representatives of all of the selected for this study Asian countires held reports - representatives of China (China Association for Public 
Companies, CAPCO), India (Institute of Company Secretaries of India) and Indonesia (Indonesia Financial Services Authority) [OECD Asian Roundtable on Corporate Governance, 2015]. At the next meeting of the OECD-Asian Roundtable on Corporate Governance, on 24-25 October 2016, the participants discussed the implementation of the new Principles in Asian context, the perspectives of corporate governance for the next 5-10 years, the disclosure of beneficial ownership and control, the role of stock exchanges in corporate governance, etc. [OECD Asian Roundtable on Corporate Governance, 2016].

Some countries have held their international events without the OECD involvement. For example, the Indian Institute of Financial Directors announced 2016 the year of corporate governance, and on 15 April 2016, it held an International roundtable on corporate governance in New Delhi (India). The roundtable was attended by representatives of corporations, regulators, and research organizations.

The OECD Latin American Roundtable on Corporate Governance (Brazil is its member) has not yet touched upon the issues of implementation of the new G20/ OECD document. Despite this, Brazil has been actively interacting with OECD in the field of corporate governance. At the end of 2015, OECD launched a joint programme of work with Brazil for 2016-2017. This programme envisages intensive interaction of Brazil with OECD committees and working groups, so that Brazil could accept international standards in a number of areas, as well as engaging Brazil in the development of international standards, including in the area of corporate governance. It is expected that not only Brazil will benefit from this cooperation, but also OECD countries [OECD, 2016b].

Russia has made quite a lot of efforts to improve legislation in the field of corporate governance and to assess the quality of corporate governance in the largest companies. It should be noted, that the last amendments to the laws "On public companies" and "On the securities market," which entered into force on July 1, 2016, allowed shareholders to receive information on corporate actions, as well as participate in the general meeting of shareholders and take some other actions in electronic form. This directly corresponds to the G20/OECD Principles of corporate governance, that call to engage shareholders in the voting process.

In 2016, Russia approved the roadmap "Improvement of corporate governance," for 2016-2018 (order of the Government of the Russia Federation No. 1315-r of 25 June 2016 № 1315-p). This document is expected to strengthen the protection of minority shareholders' rights and to improve Russia's positions on the World Bank's Doing Business "Protecting minority investors" indicator (from 5.67 points in 2016 and 5.7 points in 2017 to $6.67-6.83$ points in 2018. To achieve this goal, the document calls to strenghten the requirements for information disclosure (related party transaction), to introduce a mandatory information disclosure on transactions of all corporate group members for joint stock companies, to formalize in legislation the provisions on the audit committee of the board and on the organization of internal audit and internal control and risk management system, to introduce a mechanism for disclosing infor- 
mation on remuneration and compensation of top managers and board members, etc. [Pravitel'stvo Rossii, 2016].

When forming Russian methodology for assessing the implementation of the best practices of corporate governance, Russia took into account OECD expertise and practice, to which it gained access during its participation in the OECD work on updating the methodology for assessing the implementation of the revised G20/OECD Principles [Bank Rossii, 2016a].

In 2016, according to the "The work plan for the cooperation of the Russian Federation with the Organization for Economic Cooperation and Development (OECD) for 2016," Russia and OECD realized a joint project "Assistance in reforming the legislation of the Russian Federation in the sphere of corporate governance." In 2017, a similar plan was adopted for 2017-2018 [Bank Rossii, 2016b].

At the last meeting of the OECD - Russia Corporate Governance Roundtable, in November 2016, the National Index of Corporate Governance was presented, which was compiled by the National Association of Corporate Directors (NACD) and RSPP in order to assess the compliance of Russian companies with the principles of the Code of corporate governance. According to the results of the survey, in 2016, companies were complying with the code recommendations at 67.38 percent. The survey concluded that compared to 2015 the share of women on the Russian boards has not increased - it stayed at 8 percent level. The share of independent directors increased from 25 to 35 percent. The attendance at meetings of the boards has slightly increased - from 93 to 95 percent. The list of companies with best corporate governance practices included Sistema, Bashneft, Cherkizovo Group, MMK Group, Megafon, MTS, Rosneft, Sberbank, Severstal, TMK [Natsional'naya assotsiatsiya korporativnykh direktorov, 2016].

Starting with 2017, the Bank of Russia pledged to publish annual reviews of corporate governance practices that will monitor the implementation of the new Corporate Governance Code in Russian companies. The first survey of the Bank of Russia was published in April 2017 [Bank Rossii, 2017]. It was compiled on the basis of voluntarily completed forms, which were sent by 84 public companies ( 85 percent of all public companies that have their shares in the MICEX quotation lists). According to the general conclusions of the Bank of Russia, none of the public companies have achieved 100 percent compliance with the Code recommendations (though one company demonstrated compliance by 97,5 percent), and the average level of compliance was 58 percent.

Similar efforts have been undertaken with varying intensity by other selected for this study countries. In recent years, the Securities and Exchange Commission of Brazil has stimulated the participation of minority shareholders through a mechanism allowing all shareholders to send their votes through Internet before the general shareholder meeting. The introduction of this mechanism will become mandatory for the largest companies in 2017, for all companies - in 2018 [Calkoen, 2016].

In September 2015, Brazil stock exchange BM\&FBOVESPA started to reform the system of corporate governance at state-owned enterprises. The reform is aimed 
at restoration of investor confidence in state-owned companies through increasing the transparency of such companies, introduction of internal control measures (developing internal codes of corporate governance and conducting trainings on the application of their recommendations, etc.), revision of the boards composition (minimum requirements for the appointment of directors, 30 percent of directors should be independent). Moreover, from August 2017 on, the majority of members of risk management committees, as well as the majority of board members of systemically important financial institutions should be independent [Financial Stability Board, 2017]. The Congress of Brazil is currently discussing a bill that will introduce corporate governance rules for state-owned enterprises [ICLG, 2016].

In 2014, the Financial services authority of Indonesia (OJK), which regulates and supervises financial services markets, published the Indonesia Corporate Governance Roadmap that containes plans on major reforms in the sphere of corporate governance [KPMG, 2016]. The document is aimed at improving corporate governance in five aspects: corporate governance framework (i.e., developing codes of corporate governance), protection of shareholders, the role of stakeholders (anticorruption policies and their disclosure in annual reports, equity-based payments to employees), information transparency (shareholder disclosure, sufficient information disclosure in Indonesian and English at the corporate websites), as well as board's role and responsibilities [The Jakarta Post, 2014].

On 17 November 2015, the Financial services authority of Indonesia issued a circular letter containing the Guide on corporate governance for public companies. On the same day, the authority issued an order No. 21/POJK.04/2015, which requires public companies to comply with the principle "comply or explain" from 31 December 2016, according to the new guide. The Guide on corporate governance for public companies requires companies to create and disclose voting procedures and when possible to create closed (confidential) voting procedures. The minutes of the annual shareholders' meeting must be published on time on the website. Companies should develop and implement a policy of communication with shareholders/investors. Members of the board of directors must have different experiences and competences in order to prevent group thinking. A policy of self-monitoring of the board is necessary as well as regular evaluations. Members of the boards must resign in case the facts of their involvement in financial crimes are discovered. A policy to prevent insider trading, corruption and fraud is needed, as well as a policy of informing management about illegal activities of company employees. Public companies should disclose their ultimate beneficiaries who own at least 5 percent of the shares [KPMG, 2016].

\section{Real Implementation of the New Principles: Russia and other BRICS countries as well as Indonesia}

From the formal point of view Russia and some other selected for this study countries have recently taken actions to improve their corporate governance systems and 
to implement both the recommendations of their corporate governance codes and the revised G20/OECD Principles of corporate governance. The real effect of these actions is still difficult to assess, because not enough time has passed; moreover, a number of corporate governance problems so far remains relevant. For example, according to the 2017 report of the Laboratory for business communication studies of the Higher School of Economics and Professional investors association [Nauchno-uchebnaya laboratoriya issledovaniy v oblasti biznes-kommunikatsiy VShE, Assotsiatsiya professional'nykh investorov, 2017], which analysed the quality of the corporate governance in 13 largest Russian state companies, less than 50 percent of these companies have independent directors, and the existing independent directors are often only formally independent from the government or other controlling shareholder. At the same time, minority shareholders demonstrate low activity.

As for minority shareholders, in some selected for research countries, their positions in recent years have deteriorated. Thus, according to the IMF research, India belongs to a small group of countries, where in 2006-2014 the protection of minority shareholders' rights worsened. Also during this time, transparency in reporting and auditing has decreased [IMF, 2016]. Other countries have demonstrated improvements. For example, according to the same source, in 2006-2014, China has been consistently strengthening protection of minority shareholders [IMF, 2016].

According to [Nauchno-uchebnaya laboratoriya issledovaniy $\mathrm{v}$ oblasti bizneskommunikatsiy VShE, Assotsiatsiya professional'nykh investorov, 2017], recent years have seen significant improvements in the sphere of information disclosure aming Russian companies - almost all public companies publish information in Russian and English. However, data on shareholders who proposed candidates to the board or put the issue on the agenda of the general meeting of shareholders are not always complete. Information on related-party transactions is also disclosed reluctantly. Dividend policies are not always clear. The disclosure of information on the remuneration of top managers is insufficient. The assessment of investors' perception of the quality of corporate governance varies from 1.6 out of 5.0 points in Transneft and 1.85 points in Gazprom to 4.07 points in Sberbank. That is, there is a risk that the quality of corporate governance in some of the largest public companies is extremely low.

The key conclusion of the Deloitte study "Corporate governance structures of Russian public companies in 2015" was that after 2012, the trend of improving corporate governance in public companies in Russia was replaced by stagnation. Also, the study notes the slow implementation of the new Corporate Governance Code. For example, only 41 percent of the surveyed companies were complying with the recommendation of the Code on the share of independent directors (33 percent) [Deloitte, 2016]. The authors of the report attribute the deterioration in the dynamics of corporate governance development in Russia to the fact that during the past decade the key factor of improvements was the pressure from international capital markets. Recently, the impact of this factor has decreased. 
Formal indicators and surveys of market participants on the state of corporate governance in specific companies give different results. In particular, this conclusion was drawn from the results of the study "Index of corporate governance - 2016," which was conducted by the Association of independent directors and the National research university - the Higher School of Economics [Assotsiatsiya nezavisimykh direktorov, NIU VShE, 2016]. Top-10 companies with highest scores by formal criteria were headed by Sberbank, Inter RAO UES and Rosneft. At the same time, none of these companies was included in the top 10 companies with the highest scores according to the survey of respondents. The leaders in this list were Moscow Exchange, MTS and Enel Russia. Among the companies with the highest discrepancy between the results of the survey and the results of the evaluation by formal criteria were Enel Russia, Polyus, E.On Russia, Novatek, MTS, TGC-1, Lukoil.

According to the G20/OECD Principles of corporate governance (part V.A.5), "national principles, and in some cases laws, (...) recommend that a significant part, in some instances a majority, of the board should be independent." In Russia, according to the report of the Association of independent directors "The development of the Institute of Independent Directors" [Assotsiatsiya nezavisimykh direktorov, 2015], in 2015 , only 30 percent of directors were regarded as independent ${ }^{4}$. This does not correspond even to the Russian corporate governance code, which recommends to have at least $1 / 3$ of independent directors - i.e., more that 33 percent. For comparison, in India, according to multiple sources, including the representatives of government bodies, independent directors are not actually independent at all [Indiatoday, 2017].

The new version of the G20/OECD Principles pays attention to the gender diversity of the boards ("Countries may wish to consider measures such as voluntary targets, disclosure requirements, boardroom quotas, and private initiatives that enhance gender diversity on boards and in senior management", - part VI.E.4). In Russia, women are traditionally underrepresented on boards, as well as in managerial positions. Moreover, according to the report of the Association of independent directors "The Development of the Institute of Independent Directors" [Assotsiatsiya nezavisimykh direktorov, 2015], in 2015, their share on boards of Russian companies has decreased by $16 \%$. This is contrary to international trends, which indicate a growth in the representation of women on boards of public companies. According to Deloitte Touche Tohmatsu [Deloitte, 2015], in 2015, in some countries the share of women on boards was quite high: in Norway the value of this indicator reached 36.7 percent, in France - 29.9 percent, in Sweden -24.4 percent, in Italy -22.3 percent. Though we shall admit, that the average share of women on boards in the world is still quite low - about 12 percent, and the low average value is provided not only by developing countries, by also by some developed ones, e.g., by the U.S. and Japan. In 2015, the value of this indicator in Russia

${ }^{4}$ It should be noted that different assessments of the quality parameters of corporate governance in Russia differ significantly from each other. For example, the data presented here is different from the data, which were presented above. 
was twice as low as the world average -5.7 percent. Among Russian public joint-stock companies, there was not a single case where a woman was the chairman of a board.

According to a report of Deloitte [Deloitte, 2015], women play a significant role in Russian corporate governance, however, at present, there are no norms in Russia aimed at strengthening their role. There is also no policy to encourage the appointment of women to the boards of Russian state-owned enterprises. For comparison, France and Italy managed to achieve high results, among other things, due to the introduction of the requirement for mandatory gender diversity of the boards.

Many other selected for this research countries face problems in the practical implementation of the gender diversity of the boards. For example, boards of Indian public companies were required to include at least one woman by October 1, 2014, but many companies did not comply with this requirement. Out of 1,500 of public companies that have listing at the National Stock Exchange of India (NSE), 147 companies (12 percent) did not cope with this task even after the deadline was extended by six months. Other 770 companies employed women, which cannon be considered as independent (i.e., they are close relatives of top managers) [Sehgal, 2015].

The G20/OECD Principles of corporate governance call countries to disclose information on their top managers' and board members' remuneration policies. "In particular, it is important for shareholders to know the remuneration policy as well as the total value of compensation arrangements made pursuant to this policy. Shareholders also have an interest in how remuneration and company performance are linked when they assess the capability of the board and the qualities they should seek in nominees for the board" (part II.C.4). "Disclosure on an individual basis (including termination and retirement provisions) is increasingly regarded as good practice and is now mandated in many countries. In these cases, some jurisdictions call for remuneration of a certain number of the highest paid executives to be disclosed, while in others it is confined to specified positions" (part V.A.4).

In 2016, the Bank of Russia considered the opportunity to introduce mandatory disclosure of information on bonuses of top managers and members of corporate boards starting from 2017. According to the Bank of Russia's draft document, the regulator could oblige companies to publish key performance indicators, on which the remuneration of top managers and board members depends [Bank Rossii, 2016c]. The regulator agreed that disclosure of remuneration data could make companies more transparent. However, back in 2016, the Bank of Russia considered that the publication of information on the remuneration of certain top managers could increase tensions in society and create criminal threats. Companies can still volutarily disclose information on the remuneration of their top managers, but they usually prefer not to do this. Only the total amount of remuneration of all members of the board is mandatory for disclosure. As a rule, the relationship between the remuneration of top managers and other managers and the performance of the company is unclear.

A survey of the Laboratory for business communication studies of the Higher School of Economics and Professional investors association in 2017 [Nauchno-ucheb- 
naya laboratoriya issledovaniy v oblasti biznes-kommunikatsiy VShE, Assotsiatsiya professional'nykh investorov, 2017] has shown that in many Russian companies it is common to pay quarterly bonuses, which is not usual for the rest of the world. At the same time, the long-term reward system is often absent. According to survey respondents, it is necessary to disclose information on the remuneration of the five most highly paid managers or on the remuneration of each executive body. Also important is the publication of long-term and short-term components of remuneration and the principles of their formation. Another feature of Russian corporate governance is that companies generally do not have a thorough long-term program of management motivation, and managers do not expect to receive bonuses in 2-3 years, when the result of their efforts will become clear, as they do not hope to work so long in companies and are afraid of cheating [Podtserob, 2017].

Interestingly, in 2009, Brazil introduced a new system for disclosing information on the incomes of managers. Up to 2009, Brazil companies were required to provide only general information about their remuneration policy and disclose only the aggregate amount of payments to top managers and directors. Since 2009, companies have become obliged to publish data on minimum, average and maximum remuneration. It should be noted that this innovation was met with strong resistance from companies. Representatives of the Brazilian Institute of Financial Directors (IBEF) stated that disclosure of the maximum amount of compensation will subject the first persons of companies to the risk of criminal attacks and kidnapping. Some companies have been granted permission not to comply with this rule and are still using it [COPPEAD, 2016; ICLG, 2016].

No less interesting is that, despite the recommendations of the revised G20/ OECD Principles on increasing transparency of the management remuneration policies, in 2016, India decided to simplify the disclosure of information on remuneration and to abandon the policies under which the compensation of managers would depend on the results [Arora, 2016].

In some Russian state companies, boards work only formally, and key decisions are taken by the main owner - the state - and then "pushed down" to the boards, which automatically approve them [Bank Rossii, 2016c]. According to the G20/OECD Principles of corporate governance, (part VI), "The corporate governance framework should ensure the strategic guidance of the company, the effective monitoring of management by the board, and the board's accountability to the company and the shareholders." (...) "In addition, boards are expected to take due regard of, and deal fairly with, other stakeholder interests including those of employees, creditors, customers, suppliers and local communities. Observance of environmental and social standards is relevant in this context" (Ibid.). Thus, in a number of Russian companies international principles are completely ignored.

Moreover, as mentioned above, Russian companies are characterized by high concentration of capital, and key shareholders are often too deeply involved in the process of management, which dilutes the role of the board and makes it merely formal. 
Also, many members of the boards are not sufficiently active or are insufficiently competent. Another interesting feature of Russian boards is that, according to $\mathrm{PwC}$ data, 33 percent of boards do not assess their performance, and another 51 percent of boards conduct only self-assesment. Independent assesment is conducted only by 29 percent of boards, another 13 percent of boards conduct both self-assesment and independent assesment [Podtserob, 2017]. However, as noted in the G20/OECD Principles of corporate governance, "many countries have moved to recommend, or indeed mandate, self-assessment by boards of their performance as well as performance reviews of individual board members and the Chair and the CEO" (part VI.D.2).

\section{Conclusion}

The author has analyzed the implementation of the newly revised G20/OECD Principles of corporate governance in Russia and other BRICS countries as well as in Indonesia. Special attention has been paid to key implementation facts, both formal (introduction of new rules, adoption of new programs, etc.), and real ones (quantitative results of studies and surveys, publicly available expert commentaries). Following the analysis of these facts, conclusions have been drawn about the intensity of Russia's efforts to implement the revised document, in comparison to the efforts of other developing countries selected for the study.

The last (2015) revision of the principles of corporate governance was generally minor, though it addressed some important issues resulting from the global financial and economic crisis of 2008-2009. Since the revision actively involved several developing countries, implementation of the document in these countries is of particular interest.

Both Russia and other selected for this study countries adopted their corporate governance codes about 15-20 years ago. Later countries renewed the content of these documents several times harmonizing it with the recommendations of the OECD principles; they have also taken effort to implement the provisions both of their codes and of the principles. The Russian corporate governance code was last revised in 2014, and this revision was followed by an active work on its implementation.

The author concludes that Russia, Brazil and Indonesia have been most active in the sphere of formal implementation. These countries have been substantially involved in international discussions on the implementation of the revised document, they have been adopting legislative changes and developing government programs to improve the quality of the corporate governance. India has partially implemented the Principles. Compared to Russia, Brazil and Indonesia, this country lacked initiative and action. China lacked almost any implementation effort at all, though it was quite active in improving corporate governance at the national level in 2006-2014, and it was also actively involved in the implementation of the new G20/OECD principles at the international level in the framework of its G20 presidency in 2016. South Africa demonstrated 
no action, except for the revision of the King Report in 2016, which plays the role of corporate governance code in this country.

As to real implementation, Russia, as well as many other countries that were selected for the study, are characterized by a large number of flaws in this sphere. This relates to transparency and information disclosure, gender diversity of the board, the share of independent directors, etc. Quality of corporate governance in some of the largest companies may be extremely poor.

Russia's efforts have been assessed as "substantial implementation." Still, taking into account the deficiency of information on the performance of other countries in English and its absence in Russian, a substantial part of data on the real progress in the corporate governance in Indonesia and BRICS countries except for Russia may be beyond this analysis. However, as follows from this article, Russia is quite active in reforming its system of corporate governance, and real corporate governance environment in all selected for this study countries is not sufficiently friendly.

\section{References}

Arora R. (2016) Salary Reporting Norms Eased for India Inc. The Economic Times. Available at: http:// economictimes.indiatimes.com/news/economy/policy/salary-reporting-norms-eased-for-india-inc/ articleshow/53053308.cms (accessed 25.04.2017).

BIAC (2016) Consultation with the OECD Corporate Governance Committee, BIAC comments on future OECD work. Available at: http://biac.org/wp-content/uploads/2016/04/FIN-2016-04-corporategoverannce-consultation1.pdf (accessed 06.04.2017).

Calkoen W.J.L. (2016) The Corporate Governance Review. London: Law Business Research.

CG Watch (2016) Ecosystems Matter. Asia's Path to Better Home-grown Governance. Available at: http://www.acga-asia.org/upload/files/research_preview/20161014021202_3.pdf (accessed 01.13.2017).

COPPEAD (2016) Brazil: Recent Corporate Governance Advancements and Retreats. Available at: http://www.coppead.ufrj.br/upload/publicacoes/426.pdf (accessed 01.05.2017).

Deloitte (2015) Women in the Boardroom. A global perspective. Available at: https://www2.deloitte. com/content/dam/Deloitte/global/Documents/Risk/gx-ccg-women-in-the-boardroom-a-global-perspective4.pdf (accessed 25.04.2017).

Deloitte (2016) Struktury korporativnogo upravlenija rossijskih publichnyh kompanij v 2015 g. [Corporate Governance Structures of Russian Public Companies in 2015]. Available at: https://www2.deloitte. $\mathrm{com} / \mathrm{ru} / \mathrm{ru} /$ pages/about-deloitte/press-releases/2016/corporate-governance-structures-of-public-russian-companies.html (accessed 15.04.2017). (In Russian.)

European Corporate Governance Institute (2016) Index of Codes. Available at: http://www.ecgi.org/ codes/all_codes.php (accessed 09.03.2017).

Financial Stability Board (2017) Thematic Review on Corporate Governance, Peer Review Report. Available at: http://www.fsb.org/2017/04/fsb-publishes-thematic-peer-review-on-corporate-governance/ (accessed 05.05.2017).

G20/OECD (2015) G20/OECD Principles of Corporate Governance. Available at: http://www.oecdilibrary.org/governance/g20-oecd-principles-of-corporate-governance-2015_9789264236882-en (accessed 22.03.2017).

G20/OECD (2016) Progress Report on the Implementation of the G20/OECD Principles of Corporate Governance. Available at: https://www.oecd.org/corporate/G20-OECD-Progress-Report-on-Corporate-Governance-Principles.pdf (accessed 06.04.2017). 
IBGC (2016) Code of Best Practices of Corporate Governance, 5th Edition. Available at: http://www. ibgc.org.br/userfiles/2014/files/CMPGEN.pdf (accessed 02.03.2017).

ICLG (2016) Brazil. Corporate Governance 2016. Available at: http://www.iclg.co.uk/practice-areas/ corporate-governance/corporate-governance-2016/brazil (accessed: 01.03.2017).

ICLG (2016) Brazil. Corporate Governance 2016. Available at: https://www.issgovernance.com/file/ policy/2017-brazil-voting-guidelines.pdf (accessed: 01.05.2017).

IFC (2016) IFC Stakeholder Consultation and Practice Group Meeting on Corporate Governance Codes and Standards - Integrating Sustainability and Governance, the Role of Codes, Standards and Disclosure. Available at: http://www.ifc.org/wps/wcm/connect/c7bbf5eb-ba6d-4206-a453-f31bf 7b669aa/The_new_brazilian_Practice_Group_Meeting_on_Codes.pdf?MOD=AJPERES (accessed 03.03. 2017).

IMF (2016) Global Financial Stability Report (GFSR). Chapter 3. Corporate Governance, Investor Protection and Financial Stability in Emerging Markets. Available at: http://www.imf.org/external/pubs/ft/ gfsr/2016/02/pdf/c3.pdf (accessed 01.05.2017).

India today (2017) Sebi Flags Concerns over Corporate Governance Practices. Available at: http://indiatoday.intoday.in/story/sebi-flags-concerns-over-corporate-governance-practices/1/940737.html (accessed 28.04.2017).

Institute of Directors Southern Africa (2016) King IV Report on Corporate Governance for South Africa. Available at: http://www.iodsa.co.za/?kingIII (accessed 28.02.2017).

IOSCO (2016) Report on Corporate Governance. Available at: http://www.iosco.org/library/pubdocs/ pdf/IOSCOPD544.pdf (accessed 25.02.2017).

KPMG (2016) OJK - Corporate Governance Guideline for Public Companies. Available at: https:// home.kpmg.com/content/dam/kpmg/pdf/2016/05/tnf-indonesia-corporate-guidance-april-2016.pdf (accessed 22.04.2017).

OECD (2016a) Russia Corporate Governance Roundtable Agenda. Available at: http://www.oecd.moex. com/s631 (accessed 06.04.2017).

OECD (2016b) Launch of Brazil-OECD Programme of Work 2016-2017. Available at: http://www.oecd. $\mathrm{org} / \mathrm{brazil} /$ launch-of-brazil-oecd-programme-of-work-2016-2017.htm (accessed 11.04.2017).

OECD (2017a) Methodology for Assessing the Implementation of the G20/OECD Principles of Corporate Governance. Available at: http://www.oecd-ilibrary.org/docserver/download/2617041e.pdf?expire $\mathrm{s}=1493555852 \& \mathrm{id}=\mathrm{id} \&$ accname $=$ guest $\&$ checksum $=25 \mathrm{ED} 661 \mathrm{~B} 6 \mathrm{~B} 9 \mathrm{C} 743 \mathrm{E} 3 \mathrm{~F} 6 \mathrm{C} 8 \mathrm{C} 9 \mathrm{E} 8 \mathrm{DDB} 4 \mathrm{FA} 4($ ac cessed 06.04.2017).

OECD (2017b) OECD Corporate Governance Factbook. Available at: http://www.oecd.org/daf/ca/ Corporate-Governance-Factbook.pdf (accessed 08.04.2017).

OECD Asian Roundtable on Corporate Governance (2015) Summary Note. Available at: http://www. cgthailand.org/TH/Development/GoodGovernance/Documents/2015\%20Asian\%20Roundtable\%20 Summary\%20Note.pdf (accessed 01.03.2017).

OECD Asian Roundtable on Corporate Governance (2016) Draft Agenda. Available at: http://www.oecd. org/daf/ca/Asian-Corporate-Governance-Roundtable-Seoul-October-2016.pdf (accessed 21.04.2017).

Reuters (2014) SEBI Approves New Corporate Governance Code. Available at: http://in.reuters.com/ article/india-sebi-corporate-governance-code-idINDEEA1C0E620140213 (accessed: 01.05.2017).

Sehgal K. (2015) Indian Companies in Mad Rush to Find Women Board Members. CNN Money. Available at: http://money.cnn.com/2015/04/06/investing/india-corporate-boards-women/ (accessed 12.04. 2017).

The Jakarta Post (2014) Sipahutar T. OJK Launches Roadmap for Good Corporate Practice. Available at: http://www.thejakartapost.com/news/2014/02/05/ojk-launches-roadmap-good-corporate-practice. html (accessed 22.04.2017). 
University of Toronto (2015) G20 Leaders' Communiqué Antalya Summit, 15-16 November. Available at: http://www.g20.utoronto.ca/2015/151116-communique.pdf (accessed 22.03.2017).

Assotsiatsiya nezavisimykh direktorov (2015) Razvitie instituta nezavisimykh direktorov. Available at: http://www.nand.ru/upload/razvitie-instituta-nezavisimix-directorov-2015.pdf (accessed: 15.04.2017).

Assotsiatsiya nezavisimykh direktorov, NIU VShE (2016) Indeks korporativnogo upravleniya - 2016. Available at: http://www.nand.ru/upload/medialibrary/Russian_Corporate_Governance_Index_2016. pdf (accessed: 15.04.2017).

Bank Rossii (2016a) Prikaz Tsentral'nogo Banka Rossiyskoy Federatsii (Banka Rossii) “O realizatsii v banke Rossii Plana raboty po vzaimodeystviyu Rossiyskoy Federatsii s Organizatsiey ekonomicheskogo sotrudnichestva i razvitiya (OESR) na 2016 god”. Available at: http://cbr.ru/today/ms/smo/od-1333.pdf (accessed: 07.03.2017).

Bank Rossii (2016b) Prikaz Tsentral'nogo Banka Rossiyskoy Federatsii (Banka Rossii) "O realizatsii v banke Rossii Plana raboty po vzaimodeystviyu Rossiyskoy Federatsii s Organizatsiey ekonomicheskogo sotrudnichestva i razvitiya (OESR) na 2017-2018 gody”. Available at: http://cbr.ru/today/ms/smo/od1333.pdf (accessed: 07.03.2017).

Bank Rossii (2016c) Poyasnitel'naya zapiska k proektu ukazaniya Banka Rossii “O vnesenii izmeneniy v Polozhenie Banka Rossiiot 30 dekabrya 2014 goda № 454-P "O raskrytii informatsii emitentami emissionnykh tsennykh bumag".

Bank Rossii (2017) Obzor praktiki korporativnogo upravleniya v rossiyskikh publichnykh obshchestvakh. Available at: http://www.ao-journal.ru/news/bank-rossii-podgotovil-pervyj-obzor-praktiki-korporativnogo-upravlenija (accessed: 28.04.2017).

Larionova M.V., Lanshina T.A. (2016) Sotrudnichestvo OESR i “Gruppy dvadtsati” v tselyakh povysheniya kachestva korporativnogo upravleniya. Vestnik mezhdunarodnykh organizatsiy: obrazovanie, nauka, novaya ekonomika, vol. 11, no 4, pp. 60-76. Available at: https://iorj.hse.ru/2016-11-4/198185560.html (accessed: 22.03.2017)

Nauchno-uchebnaya laboratoriya issledovaniy v oblasti biznes-kommunikatsiy VShE, Assotsiatsiya professional'nykh investorov (2017) Otsenka korporativnogo upravleniya v publichnykh aktsionernykh obshchestvakh s uchastiem Rossiyskoy Federatsii, aktsii kotorykh obrashchayutsya na organizovannom rynke tsennykh bumag. Available at: https://buscom.hse.ru/news/205286698.html (accessed: 22.04.2017).

Natsional'naya assotsiatsiya korporativnykh direktorov (2016) Itogi Natsional'nogo indeksa korporativnogo upravleniya - 2016. Available at: http://www.corpdir.ru/news/ITOGI-NACIONALNOGOINDEKSA-KORPORATIVNOGO-UPRAVLENIYa--2016.html (accessed: 11.03.2017).

Natsional'naya assotsiatsiya korporativnykh direktorov (2016) Itogi Natsional'nogo indeksa korporativnogo upravleniya - 2016. Available at: http://www.corpdir.ru/news/ITOGI-NACIONALNOGOINDEKSA-KORPORATIVNOGO-UPRAVLENIYa--2016.html (accessed: 11.03.2017).

Podtserob M. (2017) Za chto sovety direktorov rossiyskikh kompaniy kritikuyut top-menedzherov. Vedomosti. Available at: https://www.vedomosti.ru/management/articles/2017/04/25/687257-soveti-direktorov-top-menedzherov (accessed: 27.04.2017).

Pravitel'stvo Rossii (2016) Ob utverzhdenii "dorozhnoy karty" "Sovershenstvovanie korporativnogo upravleniya”. Available at: http://government.ru/docs/23603/ (accessed: 07.03.2017).

Tsentral'nyy Bank Rossiyskoy Federatsii (2016) Pis'moot 17 fevralya 2016 goda № IN-06-52/8 "O raskrytii v godovom otchete publichnogo aktsionernogo obshchestva otcheta o soblyudeniiprintsipovirekomendatsiykodeksakorporativnogoupravleniya". Available at: http://fs.moex.com/files/13841 (accessed: 05.03.2017). 


\title{
Как Россия, другие страны БРИКС и Индонезия реализуют Принципы корпоративного управления «Группы двадцати» / ОЭСР ${ }^{1}$
}

\author{
T.А. Ланьшина
}

Ланьшина Татьяна Александровна - научный сотрудник Центра экономического моделирования энергетики и экологии ИПЭИ РАНХиГС; научный сотрудник Центра отраслевых исследований ИСКРАН; Российская Федерация, 119571, Москва, просп. Вернадского, 82, стр. 1; E-mail: lanshina@ranepa.ru

В статье проведен анализ имплементации Принципов корпоративного управления «Группы двадцати» / ОЭСР Россией в сравнении с другими странами БРИКС и Индонезией. Изначально данный документ был опубликован ОЭСР в 1999 г. Последняя (третья) версия была разработана в 2014-2015 г2. при участии стран «Группы двадиати» и принята в ноябре 2015 г. на саммите «Группы двадцати» в Анталье (Турция). Обновленный документ не претерпел кардинальных изменений по сравнению с предыдущими версиями, однако теперь он включает некоторые новые положения, внедрение которых стало необходимым после глобального финансовоэкономического кризиса 2008-2009 г2.

В центре внимания автора находятся действия выбранных для исследования стран по внедрению положений Принципов корпоративного управления «Группы двадцати» / ОЭСР, а также реальные изменения в этих странах. При проведении исследования были учтены рекомендации ОЭСР по оценке имплементации принципов корпоративного управления, в соответствии с которыми исследователям не следует заострять внимание на оценке количественных показателей. Ввиду этого автор делает акцент на качественных методах анализа и на сравнительном анализе. Выявлено, что наибольшую активность в сфере имплементации документа проявили Бразилия, Индонезия и Россия. В ЮАР и Китае наблюдалось отсутствие имплементации, в Индии частичная имплементация.

Автор отмечает, что в России, несмотря на наличие большого числа свидетельств формального внедрения принципов корпоративного управления в последние годы, реальные улучшения являются незначительными. Это касается раскрытия информации (в том числе данных о доходах менеджсеров), гендерного разнообразия советов директоров, повышения доли независимых директоров и т.д. Помимо этого, для российских компаний характерна высокая концентрация капитала, и роль советов директоров в реальности часто является лишь формальной. Тем не менее автор присваивает России оценку «существенная имплементация», в основном за инициативу, а не за результат. Также, согласно выводам статьи, аналогичные проблемы наблюдаются и в других исследованных странах.

Ключевые слова: корпоративное управление; «Группа двадцати»; ОЭСР

Для цитирования: Ланьшина Т.А. Как Россия, другие страны БРИКС и Индонезия реализуют Принципы корпоративного управления «Группы двадцати» / ОЭСР // Вестник международных организаций. 2017. T. 12. № 3. C. 137-159. DOI: 10.17323/1996-7845-2017-03-137

${ }^{1}$ Статья поступила в редакцию в январе 2017 г.

Исследование выполнено в рамках научно-исследовательской работы государственного задания РАНХиГС «Сравнительный анализ подходов стран БРИКС и Индонезии к реализации инструментов ОЭСР» 2017 г.). 


\section{Литература}

Ассоциация независимых директоров (2015) Развитие института независимых директоров. Режим доступа: http://www.nand.ru/upload/razvitie-instituta-nezavisimix-directorov-2015.pdf (дата обращения: 15.04.2017).

Ассоциация независимых директоров, НИУ ВШЭ (2016) Индекс корпоративного управления - 2016. Режим доступа: http://www.nand.ru/upload/medialibrary/Russian_Corporate_Governance_Index_2016. pdf (дата обращения: 15.04.2017).

Ларионова М.В., Ланьшина Т.А. (2016) Сотрудничество ОЭСР и «Группы двадцати» в целях повышения качества корпоративного управления // Вестник международных организаций: образование, наука, новая экономика. Т. 11. № 4. С. 60-76. Режим доступа: https://iorj.hse.ru/2016-11-4/198185560. html (дата обращения: 22.03.2017).

НИУ ВШЭ, Ассоциация профессиональных инвесторов (2017) Оценка корпоративного управления в публичных акционерных обществах с участием Российской Федерации, акции которых обращаются на организованном рынке ценных бумаг. Режим доступа: https://buscom.hse.ru/news/205286698.html (дата обращения: 22.04.2017).

Национальная ассоциация корпоративных директоров (2016) Итоги Национального индекса корпоративного управления - 2016. Режим доступа: http://www.corpdir.ru/news/ITOGI-NACIONALNOGOINDEKSA-KORPORATIVNOGO-UPRAVLENIYa--2016.html (дата обращения: 11.03.2017).

Подцероб М. (2017) За что советы директоров российских компаний критикуют топ-менеджеров // Ведомости. Режим доступа: https://www.vedomosti.ru/management/articles/2017/04/25/687257-sovetidirektorov-top-menedzherov (дата обращения: 27.04.2017).

Arora R. (2016) Salary Reporting Norms Eased for India Inc // The Economic Times. Режим доступа: http:// economictimes.indiatimes.com/news/economy/policy/salary-reporting-norms-eased-for-india-inc/articleshow/53053308.cms (дата обращения: 25.04.2017).

BIAC (2016) Consultation with the OECD Corporate Governance Committee, BIAC comments on future OECD work. Режим доступа: http://biac.org/wp-content/uploads/2016/04/FIN-2016-04-corporate-governance-consultation1.pdf (дата обращения: 06.04.2017).

Calkoen W.J.L. (2016) The Corporate Governance Review. L.: Law Business Research.

CG Watch (2016) Ecosystems Matter. Asia's Path to Better Home-grown Governance. Режим доступа: http:// www.acga-asia.org/upload/files/research_preview/20161014021202_3.pdf (дата обращения: 01.13.2017).

COPPEAD (2016) Brazil: Recent Corporate Governance Advancements and Retreats. Режим доступа: http:// www.coppead.ufrj.br/upload/publicacoes/426.pdf (дата обращения: 01.05.2017).

Deloitte (2015) Women in the Boardroom. A Global Perspective. Режим доступа: https://www2.deloitte. $\mathrm{com} /$ content/dam/Deloitte/global/Documents/Risk/gx-ccg-women-in-the-boardroom-a-global-perspective4.pdf (дата обращения: 25.04.2017).

Deloitte (2016) Структуры корпоративного управления российских публичных компаний в 2015 г. Режим доступа: https://www2.deloitte.com/ru/ru/pages/about-deloitte/press-releases/2016/corporate-governance-structures-of-public-russian-companies.html (дата обращения: 15.04.2017).

European Corporate Governance Institute (2016) Index of Codes. Режим доступа: http://www.ecgi.org/ codes/all_codes.php (дата обращения: 09.03.2017).

Financial Stability Board (2017) Thematic Review on Corporate Governance, Peer Review Report. Режим доступа: http://www.fsb.org/2017/04/fsb-publishes-thematic-peer-review-on-corporate-governance/ (дата обращения: 05.05.2017).

G20/OECD (2015) G20/OECD Principles of Corporate Governance. Режим доступа: http://www.oecdilibrary.org/governance/g20-oecd-principles-of-corporate-governance-2015_9789264236882-en (дата обращения: 22.03.2017).

G20/OECD (2016) Progress Report on the Implementation of the G20/OECD Principles of Corporate Governance. Режим доступа: https://www.oecd.org/corporate/G20-OECD-Progress-Report-on-CorporateGovernance-Principles.pdf (дата обращения: 06.04.2017). 
IBGC (2016) Code of Best Practices of Corporate Governance, 5th Edition. Режим доступа: http://www. ibgc.org.br/userfiles/2014/files/CMPGEN.pdf (дата обрашения: 02.03.2017).

ICLG (2016) Brazil. Corporate Governance 2016. Режим доступа: http://www.iclg.co.uk/practice-areas/ corporate-governance/corporate-governance-2016/brazil (дата обращения: 01.03.2017).

ICLG (2016) Brazil. Corporate Governance 2016. Режим доступа: https://www.issgovernance.com/file/ policy/2017-brazil-voting-guidelines.pdf (дата обращения: 01.05.2017).

IFC (2016) IFC Stakeholder Consultation and Practice Group Meeting on Corporate Governance Codes and Standards - Integrating Sustainability and Governance, the Role of Codes, Standards and Disclosure. Режим доступа: http://www.ifc.org/wps/wcm/connect/c7bbf5eb-ba6d-4206-a453-f31bf7b669aa/The_new_brazilian_Practice_Group_Meeting_on_Codes.pdf?MOD=AJPERES (дата обращения: 03.03.2017).

IMF (2016) Global Financial Stability Report (GFSR). Chapter 3. Corporate Governance, Investor Protection and Financial Stability in Emerging Markets. Режим доступа: http://www.imf.org/external/pubs/ft/ gfsr/2016/02/pdf/c3.pdf (дата обращения: 01.05.2017).

Indiatoday (2017) Sebi flags Concerns over Corporate Governance Practices. Режим доступа: http://indiatoday.intoday.in/story/sebi-flags-concerns-over-corporate-governance-practices/1/940737.html (дата обращения: 28.04.2017).

Institute of Directors Southern Africa (2016) King IV Report on Corporate Governance for South Africa. Режим доступа: http://www.iodsa.co.za/?kingIII (дата обращения: 28.02.2017).

IOSCO (2016) Report on Corporate Governance. Режим доступа: http://www.iosco.org/library/pubdocs/ pdf/IOSCOPD544.pdf (дата обращения: 25.02.2017).

KPMG (2016) OJK - Corporate Governance Guideline for Public Companies. Режим доступа: https://home. kpmg.com/content/dam/kpmg/pdf/2016/05/tnf-indonesia-corporate-guidance-april-2016.pdf (дата обращения: 22.04.2017).

OECD (2016a) Russia Corporate Governance Roundtable Agenda. Режим доступа: http://www.oecd.moex. com/s631 (дата обращения: 06.04.2017).

OECD (2016b) Launch of Brazil-OECD Programme of Work 2016-2017. Режим доступа: http://www.oecd. org/brazil/launch-of-brazil-oecd-programme-of-work-2016-2017.htm (дата обращения: 11.04.2017).

OECD (2017a) Methodology for Assessing the Implementation of the G20/OECD Principles of Corporate Governance. Режим доступа: http://www.oecd-ilibrary.org/docserver/download/2617041e.pdf?expires=149 3555852\&id=id\&accname $=$ guest $\&$ checksum $=25 E D 661$ B6B9C743E3F6C8C9E8DDB4FA4 (дата обращения: 06.04.2017).

OECD (2017b) OECD Corporate Governance Factbook. Режим доступа: http://www.oecd.org/daf/ca/Corporate-Governance-Factbook.pdf (дата обращения: 08.04.2017).

OECD Asian Roundtable on Corporate Governance (2015) Summary Note. Режим доступа: http://www. cgthailand.org/TH/Development/GoodGovernance/Documents/2015\%20Asian\%20Roundtable\%20Summary\%20Note.pdf (дата обращения: 01.03.2017).

OECD Asian Roundtable on Corporate Governance (2016) Draft Agenda. Режим доступа: http://www.oecd. org/daf/ca/Asian-Corporate-Governance-Roundtable-Seoul-October-2016.pdf (дата обращения: 21.04. 2017).

Reuters (2014) SEBI Approves New Corporate Governance Code. Режим доступа: http://in.reuters.com/ article/india-sebi-corporate-governance-code-idINDEEA1C0E620140213 (дата обращения: 01.05.2017).

Sehgal K. (2015) Indian Companies in Mad rush to Find Women Board Members, CNN Money. Режим доступа: http://money.cnn.com/2015/04/06/investing/india-corporate-boards-women/ (дата обращения: 12.04.2017).

The Jakarta Post (2014) Sipahutar T. OJK Launches Roadmap for Good Corporate Practice. Режим доступа: http://www.thejakartapost.com/news/2014/02/05/ojk-launches-roadmap-good-corporate-practice.html (дата обращения: 22.04.2017).

University of Toronto (2015) G20 Leaders' Communiqué Antalya Summit, 15-16 November. Режим доступа: http://www.g20.utoronto.ca/2015/151116-communique.pdf (дата обращения: 22.03.2017). 